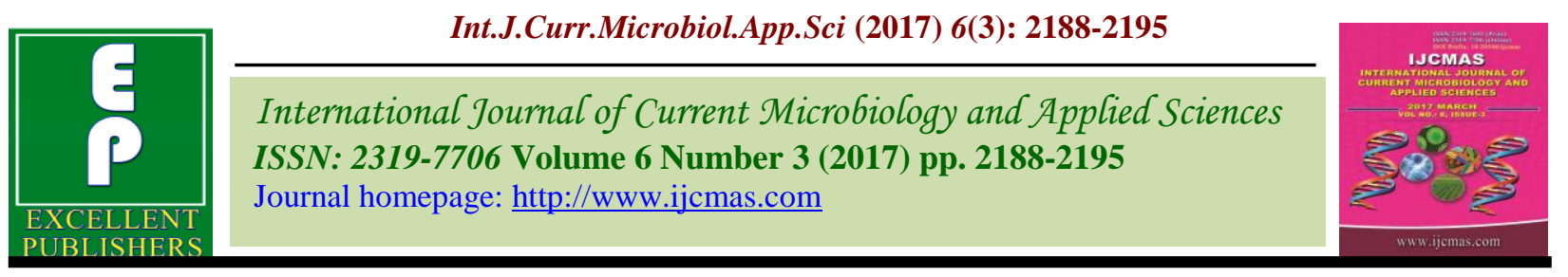

Original Research Article

https://doi.org/10.20546/ijcmas.2017.603.249

\title{
Effect of Different Genotype and Planting Geometry on Growth and Productivity of Rabi Season Pigeon Pea (Cajanus cajan L.)
}

\author{
Birendra Tigga $^{1^{*}}$, D.K. Chandraker ${ }^{1}$, Tej Ram Banjara ${ }^{2}$, \\ Sushil Kumar Bhagat ${ }^{1}$ and Manoj Dev ${ }^{1}$
}

\author{
${ }^{1}$ Department of Agronomy, College of Agriculture, IGKV, Raipur (Chhattisgarh), India \\ ${ }^{2}$ Department of Agronomy, Institute of Agricultural Sciences, Banaras Hindu University, \\ Varanasi, India \\ *Corresponding author
}

\begin{tabular}{|c|c|}
\hline & A B S T R A C T \\
\hline & \multirow{6}{*}{ 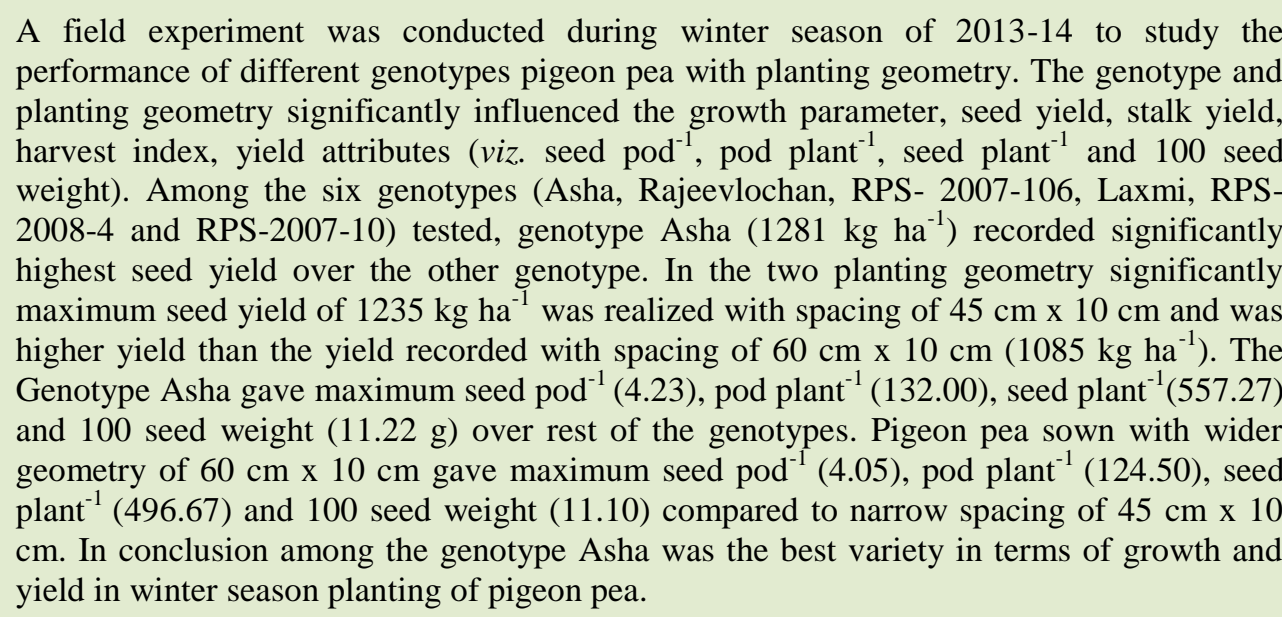 } \\
\hline Keywords & \\
\hline $\begin{array}{l}\text { Genotype, planting } \\
\text { geometry, growth } \\
\text { characters, } \\
\text { productivity. }\end{array}$ & \\
\hline Article Info & \\
\hline $\begin{array}{l}\text { Accepted: } \\
\text { 20 February } 2017 \\
\text { Available Online: } \\
10 \text { March } 2017\end{array}$ & \\
\hline & \\
\hline
\end{tabular}

\section{Introduction}

Pigeonpea (Cajanus cajan L.) is important component as it belong to leguminous family which enriches the soil by adding nitrogen, reduce soil erosion, improve physicochemical properties of the soil. Plant geometry of crop has a great role in crop growth as well as seed production. Proper plant population reflects the higher yield of crop. Control of weed flora in pigeonpea was also very important factor for higher yield. The potential yield of genotypes within its genetic limit is set by environment where it is grown. Genotypes are different in their yield potential depending on many complex physiological processes taking place in different parts of the plant, which are controlled by both genetic makeup of plant and the environment. In India it is occupying an area of 35 lakh ha with a production of 19 lakh tonnes with an average productivity of $753 \mathrm{~kg} \mathrm{ha}{ }^{-1}$ (Anonymous, 2014a). In Chhattisgarh it occupies an area of 52.85 thousands ha with production of 23.68 thousand tones with average productivity 448 
$\mathrm{kg} \mathrm{ha}^{-1}$ (Anonymous, 2014). Grain yield is product of plant populations and the single plant yield. Maximum yield in a particular cultivars and environment can be obtained at the density where competition between the plants is low. This will be attained at an optimum plant density, which not only utilizes light, moisture and nutrients more efficiently but also avoids excessive competition among the plants. Based on climatic conditions, researchers obtained differential response of mash bean in relation to row spacing. Results obtained by Davi et al., (1995) deciphered that grain yield was highest at $15 \mathrm{~cm}$ intra-row spacing. Whereas, Nagaraju et al., (1995) revealed that seed yield decreased with an increase in row spacing. Mehmud et al., (1997) indicated that increased row spacing manifested increase in the seed weight plant $^{-1}$, pod weight plant $^{-1}$, and 1000 seed weight, but decreased plant height and seed yield unit area ${ }^{-1}$. Kumar et al., (1997) obtained. The highest seed yield with row spacing of $15 \mathrm{~cm}\left(1.09 \mathrm{t} \mathrm{ha}^{-1}\right)$. However, Mishra and Mishra (1995) concluded that seed yield was not affected by row spacing. The present investigation deals with impact of different genotypes and planting geometry in winter season pigeon pea on growth and its productivity.

\section{Materials and Methods}

A field experiment was carried out during the winter season of 2013-14 at the Instructional Cum Research Farm, I.G.K.V., Raipur (C.G.). Experiment was laid out in factorial randomized block design with three replications. The treatment consisted of six genotypes viz. - Asha, Rajeev lochan, Laxmi, RPS-2008-4, RPS-2007-10 and RPS- 2007106 as factor one and two planting geometry viz. $60 \mathrm{~cm} \times 10 \mathrm{~cm}$ and $45 \mathrm{~cm} \times 10 \mathrm{~cm}$ as factor two. Geographically, Raipur is situated in the centre of Chhattisgarh and lies between $21^{0} 16^{\prime} \mathrm{N}$ latitude and $81^{\circ} 36^{\prime} \mathrm{E}$ longitudes with an altitude of $298 \mathrm{~m}$ above the mean sea level. The climatic condition of Raipur is subhumid to semi-arid and the average rainfall of locality is about $1325 \mathrm{~mm}$ year $^{-1}$. Soil sampling from the experiment field were taken with the help of a tube auger from 10 different points of the plots before starting of field experiment and were subsequently processed for further analysis for soil quality parameters. The oven dry soil samples $(<2$ $\mathrm{mm}$ ) were analyzed for $\mathrm{pH}$ (Piper, 1967), organic carbon (Walkley and Black's rapid titration method, 1934), available N (alkaline $\mathrm{KMnO}_{4}$ method by Subbiah and Asija, 1956), $0.5 \mathrm{M} \mathrm{NaHCO}_{3}$ (pH 8.5) extractable P (Olsen et al., 1984) and $1 \mathrm{~N} \mathrm{NH}_{4} \mathrm{OAc}$ extractable $\mathrm{K}$ by Flame photometric method (Jackson, 1967). The physico-chemical properties of the field soil are depicted in Table1.

The crop was sown on $23^{\text {rd }}$ November, 2013 and harvested during $5^{\text {th }}$ to $10^{\text {th }}$ May, 2014 as per genotype. Crop was fertilizes @ 20:50:20:20 kg N: $\mathrm{P}_{2} \mathrm{O}_{5}: \mathrm{K}_{2} \mathrm{O}: \mathrm{S}$. Stomp 30 EC (Pendimethalin) was applied @ 2.5 lit ha $^{-1}$ as pre-emergence to control the weeds followed by two hand weeding at 40 and 65 DAS. Two spray of Curacron $10 \%$ (Profenophos) 1 lit ha $^{-1}$ spray $^{-1}$ was done at 50 and 80 DAS as plant protection measures. The crop was given total four irrigations. The five random points in each plot were selected for recording the plant population and plant population was recorded with the help of 1 square meter quadrate.

The five plant in each plot were randomly selected and tagged for recording growth parameters and observations namely plant height, number of branches plant $^{-1}$ were recorded at harvest. However, plant population was studied at 20 DAS and at harvest. The data recorded for different characters under investigation were analyzed by following analysis of variance procedure as described by Gomez and Gomez (1984). 


\section{Results and Discussion}

\section{Genotypes}

\section{Plant population and growth characters}

The result of present investigation revealed that among different genotypes, there was non-significant variation in plant population at 20 DAS but, it was found significant at harvest (Table 2). Among the genotype maximum plant density was observed in Asha (19.08 plant $\mathrm{m}^{2}$ ) but it was statistically at par with Laxmi, RPS-2008-4, RPS-2007-10. While, planting geometry did not significantly affect on plant population at both date of observation.

It is quite clear from Table 2, Pigeonpea genotype had significantly influence on plant height, number of branches plant ${ }^{-1}$, number and dry weight of root nodules plant ${ }^{-1}$. Among the genotypes, At harvest stage Asha produced significantly taller plants (104.65 $\mathrm{cm}$ ) over rest of the genotypes. However, it was at par with Rajeevlochan, Laxmi and RPS-2007-106. This is genetic makeup of the plants or it has capability to respond better under optimum resource available. Similar observations have been reported by Soomrao and Khan (2003) Mehto et al., (2005). The variety Asha recorded significantly highest LAI over rest of other genotypes of pigeonpea tested. However it was at par with Rajeevlochan, Laxmi and RPS-2007-106. The highest leaf area index recorded by genotype Asha might be due to its genetic makeup which expresses their superiority over genetic makeup of other genotype tested under Chhattisgarh plain agro climatic condition. These results are close confirmative with the findings of Pavan et al., (2011).

\section{Yield attributing characters}

The data recorded for the yield attributing characters are presented in Table 2. Genotype
Asha recorded significantly higher number of pod plant $^{-1}$ (132 plant $\left.^{-1}\right)$, seeds pods ${ }^{-1}$ (4.23), seeds plant $^{-1}$ (557) and 100-seed weight $(11.22 \mathrm{~g})$ over other genotype tested in the experiment, which was statistically at par with genotypes Rajeevlochan, Laxmi and RPS2007-106. Variation in number of pods plant ${ }^{-1}$ might be due to genetic makeup of genotypes and response of other growth factors. Similar observations have also been recorded by Kashyap et al., (2003), Tikle and Gupta (2006).

\section{Yield}

It is quite clear from table 4 that genotype Asha recorded significantly higher seed yield $\left(1281.42 \mathrm{~kg} \mathrm{ha}^{-1}\right)$ and stover yield (5887.50 $\mathrm{kg} \mathrm{ha}^{-1}$ ) over other genotypes of pigeonpea tested in the experiment. It was statistically comparable with Rajeevlochan, Laxmi and RPS 2007-106. Asha recorded $18.03 \%$, $19.31 \%$ and $28.89 \%, 30.86 \%$ higher seed yield and stover yield than RPS-2007-10 and RPS-2008-4, respectively. This might be due to higher number of pods plant ${ }^{-1}$, more number of seeds pod ${ }^{-1}$, number of seeds plant ${ }^{1}$, higher 100-seed weight and growth characters viz. plant height, branches, LAI, dry matter accumulation resulting into higher seed yield and stover yield in Asha genotype. Each genotypes has their own yield potential which expressed in shape of plant growth and ultimately to seed yield. Similar findings have also been reported by Goswami et al., (1998). Genetic differences for seed yield have also been reported by Kashyap et al., (2003), Umesh et al., (2013).

Harvest index is a measure of physiological productivity potential of crop genotypes. It is the ability of a plant to convert the dry matter into economic yield. The difference in harvest index $(\%)$ due to genotypes was found nonsignificant. 


\section{Planting geometry}

\section{Plant population and growth characters}

As regards to planting geometry, in case of plant population and plant height of pigeon pea were found with successive decrease in planting geometry from $45 \mathrm{~cm} \times 10 \mathrm{~cm}$ to 60 $\mathrm{cm} \times 10 \mathrm{~cm}$. The results corroborate with the result recorded by Panwas and Sharma (2004) in urdbean crop. But other growth parameter was higher Significantly leaf area index, number of branches, numbers and dry weight of root nodules plant ${ }^{-1}$ observed at $60 \times 10 \mathrm{~cm}$ plant geometry over narrow planting geometry. The more number of branches plant $^{-1}$, numbers and dry weight of nodules plant $^{-1}$ in wider spacing might be due to better growth of plant because of optimum growth resources available to individual plant and their maximum utilization throughout the growth periods as per requirement of the crop. The proper and uniform density of plant stand plays the key role to increase the growth, yield attributes and seed yield of pigeonpea. If there are more plants per unit area the intra (within the plant among the plant components) and inter plant (among the plants in the area) competition for the growth resources (space, moisture, sunlight and $\mathrm{CO}_{2}$ ) will also increase. There is always competition for growth resources at all levels (micro and macro) in the field. It has established that arrangement of plants (number) per unit area should be in such a way that all plants get equal opportunity to harness the available growth resources so that variety can express their potential with respect to health and vigour which lead to yield. Singh (2012) also noted significant differences in plant population due to variation in seed rate. Similar results were recorded by Pavan et al., (2011), Meena et al., (2013) Subramani and Solaimalai (2000) and Rasul et al., (2012).

\section{Yield attributing characters}

The results data of yield attributing characters are presented in table 3. Significantly maximum number of pods plant ${ }^{-1}(124.50)$, seeds pods ${ }^{-1}$ (4.05), seeds plant ${ }^{-1}$ (496.67) and 100 -seed weight (11.10) was recorded from the plot where crop was planted in $60 \mathrm{~cm} \mathrm{x} 10$ $\mathrm{cm}\left(\mathrm{S}_{2}\right)$ over planting geometry of $45 \mathrm{~cm} \times 10$ $\mathrm{cm}$.

Table.1 Physico-chemical properties of the experimental soil

\begin{tabular}{|c|c|c|c|c|}
\hline No. & Particulars & Values & Rating & Methods \\
\hline A. & \multicolumn{4}{|l|}{ Mechanical composition } \\
\hline i. & Sand $(\%)$ & 20.55 & & \\
\hline ii. & Silt $(\%)$ & 35.26 & & International pipette method (Black, 1965) \\
\hline iii. & Clay $(\%)$ & 43.08 & $\begin{array}{c}\text { Clay } \\
\text { Vertisols }\end{array}$ & \\
\hline B. & \multicolumn{4}{|l|}{ Chemical composition } \\
\hline 1. & Organic carbon $(\%)$ & 0.54 & & $\begin{array}{l}\text { Walkley and Black's rapid titration method } \\
\text { (Jackson, 1967) }\end{array}$ \\
\hline 2. & Available $\mathrm{N}\left(\mathrm{Kg} \mathrm{ha}^{-1}\right)$ & 208 & Low & $\begin{array}{l}\text { Alkaline permangnate method } \\
\text { (Subbiah \& Asija, 1956) }\end{array}$ \\
\hline 3. & Available $\mathrm{P}\left(\mathrm{Kg} \mathrm{ha}^{-1}\right)$ & 13 & Medium & Olsen's method (Olsen 1954) \\
\hline 4. & Exchangeable $\mathrm{K}\left(\mathrm{Kg} \mathrm{ha}^{-1}\right)$ & 274 & Medium & Flame photometric method (Jackson,1967) \\
\hline 5. & $\mathrm{pH}$ value (1:2.5,soil:water) & 7.7 & Neutral & Glass electrode $\mathrm{pH}$ meter (Piper,1967) \\
\hline 6. & Electrical conductivity & 0.15 & Normal & Solubridge method, (Black,1965) \\
\hline
\end{tabular}


Table.2 Plant population and growth parameters of pigeon pea as influenced by genotypes and planting geometry

\begin{tabular}{|c|c|c|c|c|c|c|c|}
\hline \multirow{2}{*}{ Treatment } & \multicolumn{2}{|c|}{$\begin{array}{c}\text { Plant population } \\
\left(\text { No. } \mathbf{~ m}^{2}\right)\end{array}$} & \multirow{2}{*}{$\begin{array}{c}\text { Plant } \\
\text { height } \\
(\mathrm{cm})\end{array}$} & \multirow{2}{*}{$\begin{array}{l}\text { Number } \\
\text { of } \\
\text { branches }\end{array}$} & \multirow{2}{*}{$\begin{array}{l}\text { Leaf } \\
\text { area } \\
\text { index }\end{array}$} & \multirow{2}{*}{$\begin{array}{c}\text { Number } \\
\text { of root } \\
\text { nodules } \\
\text { plant }^{-1}\end{array}$} & \multirow{2}{*}{$\begin{array}{c}\text { Dry } \\
\text { weight } \\
\text { of root } \\
\text { nodules } \\
\text { plant }^{-1}\end{array}$} \\
\hline & 20 DAS & At harvest & & & & & \\
\hline \multicolumn{8}{|l|}{ Genotype } \\
\hline Asha & 20.08 & 19.08 & 104.65 & 9.66 & 1060.42 & 42.14 & 94.51 \\
\hline $\begin{array}{l}\text { Rajeev } \\
\text { lochan }\end{array}$ & 20.18 & 17.85 & 102.73 & 9.55 & 1056.08 & 41.79 & 93.38 \\
\hline Laxmi & 20.09 & 18.76 & 102.40 & 9.11 & 1021.98 & 40.85 & 91.73 \\
\hline RPS-2008-4 & 19.93 & 18.36 & 97.74 & 7.27 & 969.42 & 37.84 & 88.49 \\
\hline RPS-2007-10 & 20.04 & 18.87 & 98.16 & 8.11 & 1003.42 & 38.87 & 91.52 \\
\hline $\begin{array}{c}\text { RPS- 2007- } \\
106\end{array}$ & 19.87 & 17.91 & 102.13 & 9.22 & 1055.75 & 41.84 & 92.93 \\
\hline $\mathrm{SEm} \pm$ & 0.42 & 0.31 & 1.54 & 0.28 & 18.08 & 0.75 & 0.76 \\
\hline $\mathrm{CD}(\mathrm{P}=0.05)$ & NS & 0.93 & 4.51 & 0.82 & 53.02 & 2.19 & 2.22 \\
\hline \multicolumn{8}{|c|}{ Planting geometry } \\
\hline $\begin{array}{c}45 \mathrm{~cm} \mathrm{x} 10 \\
\mathrm{~cm}\end{array}$ & 23.38 & 21.39 & 103.83 & 8.37 & 991.55 & 39.74 & 90.90 \\
\hline $\begin{array}{c}60 \mathrm{~cm} \times 10 \\
\mathrm{~cm}\end{array}$ & 16.79 & 15.55 & 98.78 & 9.27 & 1064.14 & 41.35 & 93.29 \\
\hline $\mathrm{SEm} \pm$ & 0.24 & 0.18 & 0.88 & 0.16 & 10.44 & 0.43 & 0.44 \\
\hline $\mathrm{CD}(\mathrm{P}=0.05)$ & 0.71 & 0.53 & 2.61 & 0.48 & 30.61 & 1.26 & 1.28 \\
\hline Interaction & $\mathrm{NS}$ & $\mathrm{NS}$ & $\mathrm{NS}$ & $\mathrm{NS}$ & NS & $\mathrm{NS}$ & $\mathrm{NS}$ \\
\hline
\end{tabular}

Table.3 Effect of genotypes and planting geometry on yield attributing characters of pigeon pea

\begin{tabular}{|c|c|c|c|c|}
\hline Treatment & No. of seed pod ${ }^{-1}$ & No. of pod plant ${ }^{-1}$ & $\begin{array}{c}\text { No. of seed } \\
\text { plant }^{-1}\end{array}$ & $\begin{array}{c}100 \text { Seed } \\
\text { weight }(\mathrm{g})\end{array}$ \\
\hline \multicolumn{5}{|l|}{ Genotype } \\
\hline Asha & 4.23 & 132.00 & 557.27 & 11.22 \\
\hline Rajeevlochan & 4.22 & 129.33 & 544.69 & 11.16 \\
\hline Laxmi & 3.83 & 123.22 & 471.98 & 10.90 \\
\hline RPS-2008-4 & 3.28 & 95.50 & 312.29 & 9.84 \\
\hline RPS-2007-10 & 3.44 & 105.19 & 361.89 & 10.08 \\
\hline RPS-2007-106 & 3.94 & 127.50 & 502.49 & 11.09 \\
\hline SEm \pm & 0.20 & 4.7 & 17.27 & 0.35 \\
\hline $\mathrm{CD}(\mathrm{P}=0.05)$ & 0.58 & 13.8 & 50.66 & 1.01 \\
\hline \multicolumn{5}{|c|}{ Planting geometry } \\
\hline $45 \mathrm{~cm} \mathrm{x} 10 \mathrm{~cm}$ & 3.59 & 113.08 & 420.20 & 10.33 \\
\hline $60 \mathrm{~cm} \mathrm{x} 10 \mathrm{~cm}$ & 4.05 & 124.50 & 496.67 & 11.10 \\
\hline SEm \pm & 0.11 & 2.7 & 9.97 & 0.20 \\
\hline $\mathrm{CD}(\mathrm{P}=0.05)$ & 0.33 & 8.0 & 29.25 & 0.58 \\
\hline Interaction & $\mathrm{NS}$ & NS & NS & $\mathrm{NS}$ \\
\hline
\end{tabular}


Table.4 Seed yield, stalk yield and harvest index of pigeon pea as influenced by genotypes and planting geometry

\begin{tabular}{|c|c|c|c|}
\hline Treatment & $\begin{array}{c}\text { Seed yield } \\
\left(\mathrm{kg} \mathrm{ha}^{-1}\right)\end{array}$ & $\begin{array}{c}\text { Stalk yield } \\
\left(\mathrm{kg} \mathrm{ha}^{-1}\right)\end{array}$ & $\begin{array}{c}\text { Harvest index } \\
(\%)\end{array}$ \\
\hline \multicolumn{4}{|l|}{ Genotype } \\
\hline Asha & 1281.42 & 5887.50 & 18.14 \\
\hline Rajeev lochan & 1268.48 & 5784.17 & 18.32 \\
\hline Laxmi & 1220.10 & 5578.82 & 18.33 \\
\hline RPS-2008-4 & 911.27 & 4070.48 & 18.33 \\
\hline RPS-2007-10 & 1050.38 & 4750.33 & 18.30 \\
\hline RPS- 2007-106 & 1226.47 & 5596.93 & 18.21 \\
\hline $\mathrm{SEm} \pm$ & 63.4 & 295.4 & 0.09 \\
\hline $\mathrm{CD}(\overline{\mathrm{P}}=0.05)$ & 185.9 & 866.5 & $\mathrm{NS}$ \\
\hline \multicolumn{4}{|l|}{ Planting geometry } \\
\hline $45 \mathrm{~cm} \times 10 \mathrm{~cm}$ & 1234.80 & 6172.72 & 16.67 \\
\hline $60 \mathrm{~cm} \times 10 \mathrm{~cm}$ & 1084.60 & 4383.35 & 19.87 \\
\hline SEm \pm & 36.58 & 170.6 & 0.056 \\
\hline $\mathrm{CD}(\mathrm{P}=0.05)$ & 107.31 & 500.3 & 0.165 \\
\hline Interaction & NS & NS & NS \\
\hline
\end{tabular}

Maximum number of pods plant ${ }^{-1}$ seeds pods ${ }^{1}$, seeds plant $^{-1}$ and 100 -seed weight in $60 \mathrm{~cm}$ $\mathrm{x} 10 \mathrm{~cm}\left(\mathrm{~S}_{2}\right)$ planting geometry might be due to higher number of branches and flowers plant $^{-1}$ with adequate supply of soil-moisture and nutrients. Similar results were also recorded by Antaravalli et al., (2002), Islam et al., (2008) and Kashyap et al., (2003).

Yield: From the perusal of table 4. The crop planted with row spacing of $45 \mathrm{~cm}$ and plant to plant $10 \mathrm{~cm}$ recorded significantly higher grain yield $\left(1234.80 \mathrm{~kg} \mathrm{ha}^{-1}\right)$ and stover yield $\left(6172.72 \mathrm{~kg} \mathrm{ha}^{-1}\right)$ over wider row spacing 60 $\mathrm{cm} \times 10 \mathrm{~cm}$. narrow planting of pigeonpea (45 $\mathrm{cm} \times 10 \mathrm{~cm}$ ) recorded $12.16 \%$ more yield over wider row spacing of $60 \mathrm{~cm} \times 15 \mathrm{~cm}$.

The seed yield is the chain reaction of growth parameters and yield attributing characters. In the present investigation wider spacing recorded higher value of vegetative and reproductive growth parameter of individual plants over narrow spacing. However, in terms of seed yield and stover yield narrow spacing was statistically found superior over wider spacing might be due to the fact that total number of plants (2.22 lakh plants $\mathrm{ha}^{-1}$ ) per unit area was higher over wider spacing and this higher number of plants per unit area neutralized the effect of vegetative and reproductive parameter registered in wider spaced crops. Optimum plant population is a pre-requisite for obtaining high yields (Nandan and Kumar 2005). The results are in accordance with the findings of Panwar and Sirohi (1987), Kumar and Sharma (1989), Das et al., (1996), Ali et al., (2011) and Singh et al., (2011). Significantly maximum value of harvest index (19.87 \%) was recorded under $60 \mathrm{~cm} \times 10 \mathrm{~cm}\left(\mathrm{~S}_{2}\right)$ planting geometry, over narrow planting geometry of $45 \mathrm{~cm} \mathrm{x} 10$ cm (16.67) Similar results were recorded by Asaduzzaman et al., (2010).

The interaction of planting geometry and genotypes of pigeon pea did not vary significantly in any growth and/or yield of winter season pigeonpea. 


\section{References}

Ali, A., Nadeem, M.A., Tayyab, M., Tahir, M. and Sohail, M.R. 2011. Determining suitable planting geometry for two mungbean (Vigna radiate L.) cultivars under Faisalabad conditions. Pakistan J. Biol. Sci., 4: 344-450.

Anononymous, 2014. Department of Agriculture, C.G. Government.

Antaravalli, M.B., Halikatti, S.I., Kajjidoni, S.T., Hirermath, S.M. and Koti, R.V. 2002. Influence of different population and geometry on the growth characters of pigeon pea genotypes in vertisols of Dharwad. Karnataka J. of Agril. Sci., 15(2):246-252.

Asaduzzaman, M., Sultana, S., Roy, T.S. and Masum, S.M. 2010. Weeding and pant spacing effects on the growth and yield of blackgram. Bangladesh Research Publications J., 4(1):62-68.

Black, C. A., 1965. Methods of soil analysis. American J. Madison, Wisconsin, USA: 131-137.

Das, S.N., Mukharjee, A.K. and Nanda, H.C. 1996. Effect of dates of sowing and row spacing on yield attributes factors of different varieties of French bean (Phaseolus vulgaris). Agri. Sci. Digest, 16(9): 130-132.

Davi, D., Kumar, R. and Khippal, A. 1995. Effect of different intra-row spacing on the growth of pigeon pea and urdbean intercropping. Discovery and Innovation, 9(1-2): 47-51.

Gomez, K.A. and Gomez, A.A. 1984. Statistical procedures for agricultural research. A Willey- Inter Science Publication. John Willey \& Sons, New York.

Goswami, J., Borah, U.K. and Deka, N. 1998. Performance of blackgram (Phaseolus mungo L.) varieties under different row spacing. Haryana J. Agronomy 14(1): 44-47.
Islam, S., Nanda, M.K. and Mukharjee, A.K. 2008. Effect of date of sowing and spacing on growth and yield of rabi pigeonpea (Cajanus cajan L. Millsp.). J. Crop and Weed, 4(1): 7-9.

Jackson, M.L. 1967. Soil Chemical Analysis. Prentice Hall of India Pvt. Ltd, New Delhi. 42-48.

Kashyap, T.L. Shrivastava, G.K. Lakpale, R. and Choubey, N.K. 2003. Productivity potential of pigeonpea (Cajanus cajan L. Millsp) genotypes in response to growth regulators under Vertisols of Chhattisgarh plains. Annals of Agril. Res., 24(2): 449-452.

Kumar, A. and Sharma, B.B. 1989. Effect of row spacing and seed rate on root growth, nodulation and yield of blackgram. Indian J. Agril. Sci., 59(11): 728-729.

Kumar, S.G., Gomathinayajam, P. and Rathnaswmy, R. 1997. Effect of row spacing on a dry matter accumulation of black gram. Madras Agric. J., 84(3): 160-162.

Mahto, R.N., Yadav, M.S. and Mohan, K.S. 2005. Genotype X Environment interaction in pigeonpea under rainfed conditions. Indian J. Dryland Agril. Res. Develop., 20(2):110-113.

Meena, K.C., Rao, S.K., Rao, S., Gontia, A.S. and Singh, S.K. 2013. Influence of submergence on germination and vigor of pigeonpea genotypes. Environ. Ecol., 31(3): 1245-1249.

Mehmud, M., Chiezey, U.F., Ahmed, M.K. and Rofia, I. 1997. Effect of different levels of phosphorus fertilizers and intra row spacing on the gram yield, growth and yield components of black gram (Vigna mungo L. Hepper). Discovery and Innovation, 9(1-2): 47-51.

Mishra, M. and A. Mishra. 1995. Effect of fertilizers, weed control and row spacing on summer black gram (Phaseolus mungo). Indian J. Agron, 
40(3): 434-438.

Nagaraju, A.P., Shivanandah, N.P. and Shambulingappa, K.G. 1995. Response of urdbean genotype to row spacing. Indian J. Pulses Res., 8(2): 190-191.

Nandan, R. and Kumar, D. 2005. Response of mungbean genotypes to varying plant populations. Indian Journal of Pulses Research, 18(1): 81-83.

Olsen, S.R. 1954. Estimation of available phosphorus in soil by extraction with sodium bi-carbonate. USDA. Circular No.939: 1-19.

Panwar, G. and Sharma, B.B. 2004. Effect of planting date, seed rate and row spacing on yield and yield attributes of bold seeded mungbean during summer season. Indian J. Pulses Res., 17(1): 4546.

Panwar, J.D.S. and Sirohi, G.S. 1987. Studies on effect of plant population on grain yield and its components on mungbean (Vigna radiate L.). Ind. J. Plant Physiol. 30(4): 412-415.

Pavan, A.S., Nagalikar, V.P., Pujari, B.T. and Halepyali, A.S. 2011.Influnce of planting geometry on the growth characters, seed yield and economy of transplanted pigeonpea. Karnataka $J$. Agril. Sci., 24(3): 390-392.

Piper, C.S. 1967. Soil and Plant Analysis. Asia Publishing House, New Delhi. 3038.

Rasul, F., Cheema, M.A., Sattar, A., Saleem, M.F. and Wahid, M.A. 2012. Evaluating the performance of three mungbean varieties grown under varying inter-row spacing. The $J$. Animal \& Plant Sci., 22(4):1030-1035.
Singh, G., Ram, H., Sekhon, H.S., Gill, K.K. and Khanna, V. 2011. Effect of time of planting on nodulation, growth and seed yield of kharif urdbean genotypes. $J$. Food Legumes, 25(2): 125-127.

Singh, M.V., Kumar, N. and Singh, R. K. 2012. Effect of plant geometry and methods of weed control on growth and yield of pigeonpea. Ann. Pl. Soil Res., 14(1): 36-38.

Soomrao, N.A. and Khan, H.R. 2003. Response of mungbean genotypes to different dates of sowing in kharif season under rainfed conditions. Asian J. Plant Sci., 2(4): 377-379.

Subbiah, B. V. and Asija, G. L. 1956. A rapid method for the estimation of nitrogen in soils. Curr. Sci., 26: 259-260.

Subramani, M. and Solaimalai, A. 2000. Influence of plant populations and methods of nutrient application on growth and yield of blackgram. Legume Res., 23(3): 197-198.

Tikle, A.N. and Gupta, S.C. 2006. Variability for nodulating ability of pigeonpea genotypes under field conditions. Indian J. Pulses Res., 19(1): 124-125.

Umesh, M.R., Shankar, M.A. and Ananda, N. 2013. Yield, nutrient uptake and economics of pigeonpea (Cajanus cajan L.) genotypes under nutrient supply levels in dryland Alfisols of Karnataka. Indian J. Agronomy, 58(4): 554-559.

Walkley, A. and Black, C. A., 1934. An examination method for determining soil organic matter and proposed modification of the chromic acid titration method. Soil Sci., 37: 29-38.

\section{How to cite this article:}

Birendra Tigga, D.K. Chandraker, Tej Ram Banjara, Sushil Kumar Bhagat and Manoj Dev 2017. Effect of Different Genotype and Planting Geometry on Growth and Productivity of Rabi Season Pigeon Pea (Cajanus cajan L.). Int.J.Curr.Microbiol.App.Sci. 6(3): 2188-2195. doi: https://doi.org/10.20546/ijcmas.2017.603.249 